UDC 332.02

Вестник СПбГУ. Прикладная математика. Информатика... 2019. Т. 15. Вып. 3

MSC 91B06, 91B64, 93C40, 93C42

\title{
Approach to the problem of strategic management of the regional development based on adaptive simulation model ${ }^{*}$
}

\author{
A. R. Bakhtizin ${ }^{1}$, M. M. Nizamutdinov ${ }^{2}$, V. V. Oreshnikov $^{2}$ \\ 1 Central Economics and Mathematics Institute of the Russian Academy of Sciences, \\ 47, Nakhimovsky pr., Moscow, 117418, Russian Federation \\ 2 Institute of Social and Economic Researches of the Ufa Federal Research Centre \\ of the Russian Academy of Sciences, 71, pr. Oktyabrya, Ufa, \\ 450054, Russian Federation
}

For citation: Bakhtizin A. R., Nizamutdinov M. M., Oreshnikov V. V. Approach to the problem of strategic management of the regional development based on adaptive simulation model. Vestnik of Saint Petersburg University. Applied Mathematics. Computer Science. Control Processes, 2019, vol. 15, iss. 3, pp. 362-374. https://doi.org/10.21638/11702/spbu10.2019.306

Nowadays, one of the most urgent tasks facing the state authorities in the Russian Federation is to manage the comprehensive development of the regions. The complexity of this subject to management, multidimensionality of existing problems and the inconsistency of the targets in conjunction with the dynamically changing operating conditions require the use of modern methods and tools to forecasting of changes in the key parameters of regional development. The article describes approach to the formation of an adaptive simulation model of regional socio-economic system. This model allows to take into account the behaviour of economic agents in their interaction with each other and the environment. The conceptual scheme of this model is presented. The basic elements of model, including blocks of adaptive behaviour of agents, use of resources and maintenance of balances are revealed. The control subsystem including the goal setting and control blocks is allocated separately. A set of rules governing the activation of a particular block of the model is justified. To implement this task, the adjustment mechanism of the indicative plan is formalized based on fuzzy logic methods. The knowledge base of fuzzy rules for the formation of target indicators for management of the regional system development is developed. At the end of the article the scheme of implementation of information support of regional development management based on the proposed adaptive simulation model of the region is described. In our opinion, the proposed tools which combines the methods of management theory and economic and mathematical methods will improve the efficiency of regional development strategies.

Keywords: strategy of socio-economic development, simulation modelling, adaptation, regional system, fuzzy logic, target indicators, management, decision support system.

Introduction. Currently, strategic objective of access to an innovative development model for the regions of Russia requires large-scale implementation of advanced technology and notation that provide access to a new techno-economic paradigm based on production of goods and services with higher value added nowadays. An equally important objective is formation immediately innovation-oriented system of strategic planning that could ensure the integration of potential innovate centers inside the existing exceptionally inertial model of the reproduction process. Moreover, this system could analyze impact of innovation factors on the development of economic system, mutual adapt and synchronize these processes within the framework horizon for strategic planning [1].

* This work was supported by the Russian Foundation for Basic Research (grant N 18-00-00345 (18-00-00343)).

(C) Санкт-Петербургский государственный университет, 2019 
Accordingly, the issues of the development approaches to forecasting and planning of the regional development that consider these features become update [2]. Currently, the solution of this problem is associated with several difficulties - nonconcurrence of objectives (by levels, planning horizon and subjects of management), the deficient consistency of the existing economic policies, the lack of a clear analysis system and an efficient use of management information, the immaturity of methodical aspects of strategic planning at the regional level. As a result, there is a low quality of the formed forecast estimates for the main parameters of regional development [3], which necessitate for its constant revision during the implementation of strategies.

Within this framework further development of methods of strategic planning at the regional level requires qualitative rethinking that dictated by the need to consider continuous changes of the parameters and the condition in a global competitive market environment, and its impact on the economic growth. The formation of regional development programs even in the medium term requires the implementation of mechanisms for mutual consideration of the interests and adaptation of economic agents' behaviour strategies on the different levels, the existence of prior agreement procedures, and then joint implementation, the monitoring and iteration correcting of the strategic parameters of territorial development [4]. In this context, the modern decision support technologies based on the adaptive management technique and simulation modelling can be an effective tool for the improvement methods of strategic planning [5]. These technologies allow to ensure of the qualitative information support in development and implementation of the regional economic development programmes.

A conceptual framework of the regional development modelling. The strategy of socio-economic development of the regional system includes a set of indicators (indicative plan) which describe the desired state of the system in the future, and control parameters implementation of which is aims to achieve the indicative plan. One of the main issues of development strategy is to define of the balance of interests of the key economic agents (EA). The use of management models and mechanisms seems appropriate as a tool for solving such problems [6, 7]. This toolkit should be capable of the forecasting evolutionary processes in the regional economic system in a changing of domestic and external macroenvironment, in other words it is based on the use of an adaptive method.

The proposed conception of an Adaptive Simulation Modelling (ASM) is based on the idea of the eventual adaptation of both the agent behavior strategies and the controlling action to changes in the economic environment. This conception of ASM comprises three main levels: the EA, the regional management, the macroenvironment (Figure 1) [8]. Regarding to the problem solution of development programs for the regional growth, regional economic actors are one of many EA, but it differs from other agents of the model by set of characteristics and goals inherent in them. Consequently, implementation of the functions to manage the innovative development of the region is to establish a certain condition for their activities and realized by the central and local public authorities of a region.

A set of models of the EA describes by the tuple:

$$
A=\langle M S, M F, M X\rangle,
$$

here $M S$ is the block of adaptive behavior of the EA, $M F$ is the block of resources use by the EA, $M X$ is the block of balancing income and expenditures of the EA.

Particularly, the block of EA adaptive behavior $M S=\left\langle R_{a}, S_{r}, K, Y^{f}\right\rangle$ describes the actions of EA on the use available at its disposal resources $R_{a}=\left\{R_{a t}^{1}, R_{a t}^{2}, \ldots, R_{a t}^{n_{k}}\right\}$ 


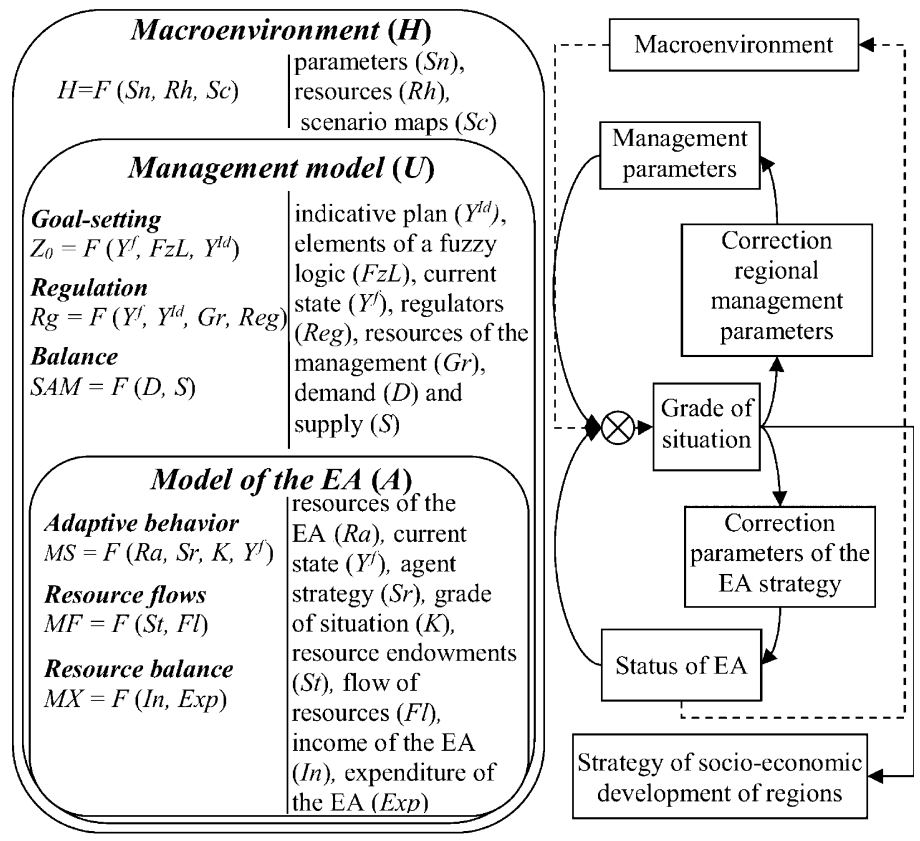

Figure 1. The conceptual framework of the adaptive simulation model of the regional socio-economic system (RSES)

in order to achieve $Y^{f}=\left\{Y_{t}^{f_{1}}, Y_{t}^{f_{2}}, \ldots, Y_{t}^{f n_{k}}\right\}$ in accordance a certain behavior strategy $S_{r}=\left\{S_{r t}^{1}, S_{r t}^{2}, \ldots, S_{r t}^{n_{k}}\right\}$ based on the current grade of situation $K=\left\{K_{t}^{1}, K_{t}^{2}, \ldots, K_{t}^{n_{k}}\right\}$ at the time $t\left(t=1,2, \ldots, T\right.$, where $T$ is the modelling horizon). Hereinafter $n_{k}$ is the number of elements, which include in the $k$-th tuple.

Adaptability of the agent behavior to changing operational conditions (by choosing of another behavior strategy which is a set of rules implemented in these conditions) is a distinctive feature of the considered block.

The block of resources $M F$ describes the changes in inventories of the EA $S t=\left\{S t_{t}^{1}\right.$, $\left.S t_{t}^{2}, \ldots, S t_{t}^{n_{k}}\right\}$ and its flows $F l=\left\{F l_{t}^{1}, F l_{t}^{2}, \ldots, F l_{t}^{n_{k}}\right\}$ at some instant $t$. Consequently, in our opinion, the use of models and methods of system dynamics as the prime tool is the most appropriate in forming a model. The block of balance analysis $M X$ ensures maintenance of the expenditure $O u t=\left\{O u t_{t}^{1}, O u t_{t}^{2}, \ldots, O u t_{t}^{n_{k}}\right\}$ on a level determined by the income and resources of the economic agent.

As shown on Figure 1, the control subsystem is represented by second level of the hierarchy and forms a model of regional management $U$ which includes two interrelated blocks - goal setting (establishment of the indicative development plan of the RSES) and regulation (formation of the control parameters that ensure the achievement of the indicative plan) which are presented in Figure 2. The choice of the solution is based on the analysis of the level of achievement of the planned values of indicators of regional socio-economic development and the availability of unused system resources (Table 1). The solution numbers in the Table 1 correspond to the solution numbers in Figure 2.

Within the framework of this model the solution of economic development issues at regional level is expected among other things.

Assessment of resources of the EA "State" $\left(G r_{t}^{s}\right)$ occurs when choosing solutions $((2)$ and $(3))$. From there, the decision to change the expenditure either on the minimum 
Table 1. A set of rules for making decisions

\begin{tabular}{|l|l|l|l|}
\hline \multicolumn{1}{|c|}{ Resource } & $\begin{array}{c}\text { The indicators } \\
\text { achieved (equally) }\end{array}$ & \multicolumn{1}{|c|}{$\begin{array}{c}\text { The indicators achieved/not } \\
\text { achieved (not equally) }\end{array}$} & $\begin{array}{c}\text { The indicators } \\
\text { not achieved (equally) }\end{array}$ \\
\hline $\begin{array}{l}\text { Resource is } \\
\text { available }\end{array}$ & $\begin{array}{l}\text { Increase of the } \\
\text { indicative plan (1) }\end{array}$ & $\begin{array}{l}\text { Increasing flow in the lagging } \\
\text { dimensions (2) }\end{array}$ & $\begin{array}{l}\text { Increasing flow in any } \\
\text { of the dimensions (3) }\end{array}$ \\
\hline $\begin{array}{l}\text { Resource is not } \\
\text { available }\end{array}$ & $\begin{array}{l}\text { Completion } \\
\text { algorithm (4) }\end{array}$ & $\begin{array}{l}\text { Reallocation of resources } \\
\text { in the dimensions (5) }\end{array}$ & $\begin{array}{l}\text { Reduction of the } \\
\text { indicative plan (6) }\end{array}$ \\
\hline
\end{tabular}

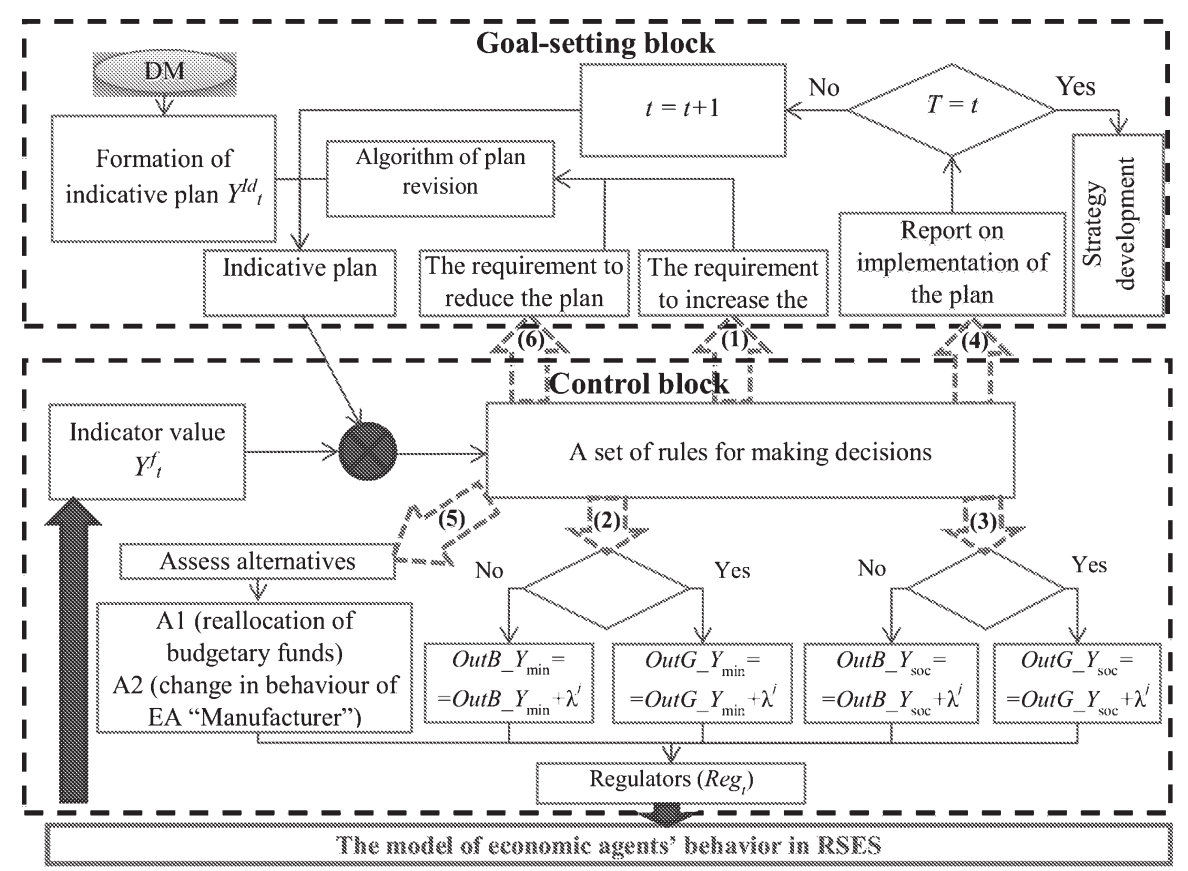

Figure 2. The algorithm of formation of target indicators and parameters of development management of RSES

achieved, or on a predetermined (for example, the tasks of social development) direction of development at the expense of state resources $\left(O u t G_{-} Y_{\min }\right.$ and $O u t G_{-} Y_{\text {soc }}$ respectively) or business resources $\left(O u t B_{-} Y_{\min }\right.$ and $\left.O u t B_{-} Y_{\text {soc }}\right)$ is taken.

The peculiarity of regional management decisions is to describe these procedures with the help of such fuzzy formulations as "slightly", "essential", etc. A few researchers note that part of the scenario conditions can be based on expert assessments [9]. It is proposed to use the algorithm of a fuzzy logic $F z L$ for implementing this approach within the framework of the developed tools which is a distinctive feature of the goal-setting block $Z_{0}$. This block $Z_{0}$ provides determination and correction of the indicative plan $Y^{I d}=\left\{Y_{t}^{I d 1}, Y_{t}^{I d 2}, \ldots, Y_{t}^{I d n_{k}}\right\}$ in time $t$ :

$$
Z_{0}=\left\langle Y^{f}, F z L, Y^{I d}\right\rangle \text {. }
$$

The original version of the indicative plan $Y_{t}^{I d}$ is formed by the decision maker in view of the current situation, trends in the development of both internal and external environment, as well as considering the development goals of the RSES. Within the framework of the regulation block $R g$ setting the regulators of the controlling system 
$R e g=\left\{R e g_{t}^{1}, \operatorname{Reg}_{t}^{2}, \ldots, \operatorname{Reg}_{t}^{n_{k}}\right\}$ are configured based on the set development goals and available resources, while monitoring the key macroindicators $Y_{t}^{f}$ at the instant of time $t$ :

$$
R g=\left\langle Y^{f}, Y^{I d}, G r, \operatorname{Reg}\right\rangle .
$$

Consequently, management of RSES includes value determination of the indicative plan which is a quantification of the of the regional development goals and ways to achieve them. The balance block SAM describes by the tuple $S A M=\langle D, S\rangle$, where $D$ and $S$ represent, respectively, the demand and supply of resources in the markets.

The model of macroenvironment $H=\langle S n, R h, S c\rangle$ is defined through the parameters $S n=\left\{S n_{t}^{1}, S n_{t}^{2}, \ldots, S n_{t}^{n_{k}}\right\}$ and resources $R h=\left\{R h_{t}^{1}, R h_{t}^{2}, \ldots, R h_{t}^{n_{k}}\right\}$ of external environment, defined by scenario card $S c$ for each time $t$. To be noticed is that the model of regional system can be obtained predictive estimates only those parameters that characterize the elements of system. Accordingly, all characteristics of the macroenvironment are exogenous parameters of the model. When determining their numerical values, it is advisable to focus on the forecasts developed by the Ministry of Economic Development of the Russian Federation. The formation of scenario maps is based on the scenario conditions used in this case.

The modelling process is based on the nesting of calculations. This procedure includes consistent calculation of $i$-th $\left(\forall i, i=\overline{1 ; i_{k}}\right.$, where $i_{k}$ is a number of parameters in the indicative plan) element $Y_{t}^{I d i}$ within the framework the nested procedure for calculating the $i j$-th combination $\operatorname{reg}_{t}^{i g}\left(\forall j, j=\overline{1 ; j_{k}}\right.$, where $j_{k}$ is a number of controlled parameters) simulating the adaptive behavior of the EA $A$. The decision to change the parameter values $r e g_{t}^{i g}, Y_{t}^{I d i}$ or move to the next model period $(t+1)$ is made based on the degree of achievement of the target indicator $Y_{t}^{I d i}$.

In this way, the proposed conception of an adaptive simulation modelling for a region is based on the hierarchical interconnection of the triad of models in a single computable complex. This makes it possible to implement an iterative mechanism of mutual adaptation of interests and strategies of the EA both in interaction with each other and in interaction with the management system in the process of development and implementation of regional development programs.

Formalization of the mechanism for adjusting the indicative plan involving the use methods of fuzzy logic. The developed approach to modelling of the procedure for adjusting the indicative development plan of the RSES is based on the use of fuzzy logic, which determines the sequence of stages as described below. The indicative plan in this context must include key indicators of socio-economic development of the region such as gross regional product, volume of fixed investment, the amount of per capita income, the amount of fiscal capacity, etc.

At the stage of fuzzification used conditions are expressed in the form of linguistic term. The solutions themselves are formed using the following criterion:

Criterion 1. Degree of indicative plan achievement is $P D_{t}^{i}=\left\{P D_{t}^{1}, P D_{t}^{2}, \ldots, P D_{t}^{n_{k}}\right\}$. Linguistic variable $P D_{t}^{i}$ can take values $P D_{t}^{i}=\{$ overfulfilled $(p d) ;$ achieved $(d) ;$ not achieved (nd)\}.

Criterion 2. The change in the rate of growth of element $i$ of the indicative plan is $T R P_{t}^{i}=\left\{T R P_{t}^{1}, T R P_{t}^{2}, \ldots, T R P_{t}^{n_{k}}\right\}$ characterizing its dynamics. The possible value of linguistic variable is $T R P_{t}^{i}=\{$ improved considerably $(m v)$; improved $(v)$; remained intact $(s)$; revised down $(n)$; revised down considerably $(m n)\}$.

Criterion 3. Ratio of growth rate element $i$ of the indicative plan and growth rates of other indicators $R P d_{t}^{i}=\left\{R P d_{t}^{1}, R P d_{t}^{2}, \ldots, R P d_{t}^{n_{k}}\right\}$. Linguistic variable $R P d_{t}^{i}$ can take 
values $R P d_{t}^{i}=\{$ significantly higher (mv); higher (v); comparable (s); below ( $n)$; far below $(m n)\}$.

Criterion 4. Availability of other indicators with the best growth rates.

The membership functions have been developed for fuzzification of the distinct reported value. It should be noted that type of these functions may vary for different regional systems. The membership function of class $L(x ; a, b)$ applied to describe the leftmost term of the study. The membership function of class $t(x ; a, b, c)$ employed to describe the middle term. The membership function of class $\gamma(x ; a, b)$ was used to describe the far-right term. These functions are standard membership functions that are easily applicable to most tasks. The choice of these functions is contingent on the analysis of the subject area considering the scientific assessment. The values of the coefficients $a, b, c$ are determined individually for each element under study.

Thus, to describe the leftmost term, apply the expression:

$$
\mu(a, b, c)= \begin{cases}1, & \text { if } x \leqslant a, \\ \frac{b-x}{b-a}, & \text { if } x<b, \\ 0, & \text { if } x \geqslant b .\end{cases}
$$

To describe the middle term, apply the expression:

$$
\mu(x, a, b, c)= \begin{cases}0, & \text { if } x \leqslant a, \\ \frac{x-a}{c-a}, & \text { if } a<x \leqslant c, \\ \frac{b-x}{b-c}, & \text { if } c<x<b, \\ 0, & \text { if } x \geqslant b .\end{cases}
$$

To describe the far-right term, apply the expression:

$$
\mu(x, a, b)= \begin{cases}0, & \text { if } x \leqslant a \\ \frac{x-a}{b-a}, & \text { if } x<b \\ 1, & \text { if } x \geqslant b .\end{cases}
$$

The calculated values of the criteria determine the fuzzy solution $\operatorname{Resh}_{t}^{i}=\left\{\operatorname{Resh}_{t}^{1}\right.$, $\left.\operatorname{Resh}_{t}^{2}, \ldots, \operatorname{Resh}_{t}^{n}\right\}$ that describes the change of the $i$-th element of the indicative plan. Accordingly, linguistic variable $R e s h_{t}^{i}$ for each indicators of the indicative plan can take values $R_{e s h}^{i}=\{$ significantly reduce $(m n)$; reduce $(n)$; save current value (s); raise (v); significantly raise $(m v)\}$.

The formation of a fuzzy knowledge base is the next step. The system of fuzzy statement is written as

$$
\bar{L}=\left\{\begin{array}{l}
\overline{L_{1}}:<\text { if } \overline{A_{1}}, \text { then } \overline{B_{1}}>, \\
\ldots, \\
\overline{L_{m}}:<\text { if } \overline{A_{m}}, \text { then } \overline{B_{m}}>.
\end{array}\right.
$$

Fuzzy statements correspond to the general form as

$$
\bar{A}_{j}:<\beta_{w} \text { is } \alpha_{w j}>\text { and } \bar{B}_{j}:<\bar{\beta}_{v} \text { is } \alpha_{v j}>,
$$

where $\alpha_{w j}, \alpha_{v j}$ are values of terms of input and output linguistic variable; $\beta_{w}, \beta_{v}$ are the terms of input and output linguistic variables. 
Knowledge base formed based on the selected criteria and analysis of the subject area. The choice of a fuzzy decision $\operatorname{Resh}_{t}^{i}$ on the change of the indicative plan implemented based on knowledge base (Table 2).

\section{Table 2. The knowledge base of a fuzzy rule algorithm of formation indicators of the development of RSES}

\begin{tabular}{|c|c|c|c|c|c|c|c|}
\hline \multirow{4}{*}{$\begin{array}{l}\text { Change in the } \\
\text { growth rate of } \\
\text { the indicator } \\
\left(T R P_{t}^{i}\right)\end{array}$} & \multirow{4}{*}{$\begin{array}{l}\text { The ratio of } \\
\text { growth rate } \\
\qquad\left(R P d_{t}^{i}\right)\end{array}$} & \multicolumn{6}{|c|}{ Degree of achievement $\left(P D_{t}^{2}\right)$} \\
\hline & & not ac & $(n d)$ & acl & & overf & $(p d)$ \\
\hline & & \multicolumn{6}{|c|}{ Availability of other indicators with the best growth rates } \\
\hline & & yes & no & yes & no & yes & no \\
\hline \multirow{5}{*}{$\begin{array}{l}\text { Improved } \\
\text { considerably } \\
(m v)\end{array}$} & $\begin{array}{l}\text { Significantly } \\
\text { higher }\end{array}$ & $n$ & $m n$ & $s$ & $s$ & $s$ & $\vec{v}$ \\
\hline & Higher & $n$ & $m n$ & $s$ & $s$ & $s$ & $v$ \\
\hline & Comparable & $n$ & $n$ & $v$ & $s$ & $s$ & $v$ \\
\hline & Below & $s$ & $n$ & $v$ & $s$ & $s$ & $v$ \\
\hline & Far below & $s$ & $n$ & $v$ & $s$ & $s$ & $v$ \\
\hline \multirow{5}{*}{$\begin{array}{l}\text { Improved } \\
(v)\end{array}$} & $\begin{array}{l}\text { Significantly } \\
\text { higher }\end{array}$ & $n$ & $n$ & $s$ & $s$ & $s$ & $v$ \\
\hline & Higher & $n$ & $n$ & $s$ & $s$ & $s$ & $v$ \\
\hline & Comparable & $n$ & $n$ & $s$ & $s$ & $s$ & $v$ \\
\hline & Below & $s$ & $n$ & $s$ & $s$ & $s$ & $v$ \\
\hline & Far below & $s$ & $n$ & $s$ & $s$ & $s$ & $v$ \\
\hline \multirow{5}{*}{$\begin{array}{l}\text { Remained } \\
\text { intact } \\
(s)\end{array}$} & $\begin{array}{l}\text { Significantly } \\
\text { higher }\end{array}$ & $s$ & $n$ & $s$ & $s$ & $v$ & $v$ \\
\hline & Higher & $s$ & $n$ & $s$ & $s$ & $v$ & $v$ \\
\hline & Comparable & $s$ & $n$ & $s$ & $s$ & $v$ & $v$ \\
\hline & Below & $n$ & $n$ & $s$ & $s$ & $s$ & $v$ \\
\hline & Far below & $n$ & $n$ & $s$ & $s$ & $s$ & $v$ \\
\hline \multirow{5}{*}{$\begin{array}{l}\text { Revised } \\
\text { down } \\
(n)\end{array}$} & $\begin{array}{l}\text { Significantly } \\
\text { higher }\end{array}$ & $s$ & $n$ & $v$ & $s$ & $s$ & $v$ \\
\hline & Higher & $s$ & $n$ & $v$ & $s$ & $s$ & $v$ \\
\hline & Comparable & $s$ & $n$ & $s$ & $s$ & $v$ & $v$ \\
\hline & Below & $s$ & $n$ & $s$ & $s$ & $v$ & $v$ \\
\hline & Far below & $s$ & $n$ & $s$ & $s$ & $v$ & $v$ \\
\hline \multirow{5}{*}{$\begin{array}{l}\text { Revised down } \\
\text { considerably } \\
(m n)\end{array}$} & $\begin{array}{l}\text { Significantly } \\
\text { higher }\end{array}$ & $s$ & $n$ & $s$ & $s$ & $s$ & $v$ \\
\hline & Higher & $s$ & $n$ & $s$ & $s$ & $s$ & $v$ \\
\hline & Comparable & $s$ & $n$ & $v$ & $s$ & $v$ & $v$ \\
\hline & Below & $s$ & $n$ & $v$ & $s$ & $m v$ & $v$ \\
\hline & Far below & $s$ & $n$ & $v$ & $s$ & $m v$ & $v$ \\
\hline
\end{tabular}

The final step is the defuzzification procedure which is necessary to determine the specific numerical value of the output parameter. Various methods ("center of gravity", "first maximum", "middle maximum" and others) can be used for this purpose [10]. The study used the method of "first maximum" characterized by simplicity of implementation. However, this approach has a few disadvantages. Slow response in terms of fuzzy model is the most significant of them. One area for further research, in our opinion, is the rationale using of the center of gravity method to solve the problem, considering the existing features of the membership function of the output parameter. Next, the truth value of each rule is calculated, and a management decision is formed.

The achievement of the indicative plan $Y_{t}^{I d}$ is carried out by changing the values of the controlled parameters $r e g_{t}^{i y}$ in accordance with the selected rules $R u_{t}^{s}$, which are a record of the form: "if $R u_{t}^{s}=t r u e$, then $r e g_{t}^{j}=r e g_{t}^{j}+\gamma^{j}$ ". A key principle of development control parameters is levelling and maximizing the degree of achievement of indicators 
$\left(\min \left(Y_{t}^{f i} / Y_{t}^{I d i}\right) \longrightarrow \max \right)$. At each modeling step, one of the situations that define the rules $R u_{t}^{s}$ is possible:

1)

$$
\left(Y_{t}^{f i} \geqslant Y_{t}^{I d i}\right) \wedge\left(\frac{Y_{t}^{f i}}{Y_{t}^{I d i}}=\frac{Y_{t}^{(f i+1)}}{Y_{t}^{(I d i+1)}}\right) \wedge\left(G r_{t}^{s}>0\right) \longrightarrow Y_{t}^{I d i}=Y_{t}^{I d i}+\lambda^{j}
$$

2)

$$
\left(\frac{Y_{t}^{f i}}{Y_{t}^{I d i}} \neq \frac{Y_{t}^{(f i+1)}}{Y_{t}^{(I d i+1)}}\right) \wedge\left(G r_{t}^{s}>0\right) \longrightarrow\left[\begin{array}{c}
\operatorname{Reg}_{t}^{i j}=\operatorname{Reg}_{t}^{i j}+\lambda^{j}, \frac{Y_{t}^{f i}}{Y_{t}^{I d i}}=\min _{i} \frac{Y_{t}^{f i}}{Y_{t}^{I d i}} \\
\operatorname{Reg}_{t}^{i j}=\operatorname{Reg}_{t}^{i j}, \frac{Y_{t}^{f i}}{Y_{t}^{I d i}} \neq \min _{i} \frac{Y_{t}^{f i}}{Y_{t}^{I d i}}
\end{array}\right.
$$

3)

$$
\left(Y_{t}^{f i}<Y_{t}^{I d i}\right) \wedge\left(\frac{Y_{t}^{f i}}{Y_{t}^{I d i}}=\frac{Y_{t}^{(f i+1)}}{Y_{t}^{(I d i+1)}}\right) \wedge\left(G r_{t}^{s}>0\right) \longrightarrow \operatorname{Reg}_{t}^{i j}=\operatorname{Reg} g_{t}^{i j}+\lambda^{j}
$$

4)

$$
\left(Y_{t}^{f i} \geqslant Y_{t}^{I d i}\right) \wedge\left(\frac{Y_{t}^{f i}}{Y_{t}^{I d i}}=\frac{Y_{t}^{(f i+1)}}{Y_{t}^{(I d i+1)}}\right) \wedge\left(G r_{t}^{s}=0\right) \longrightarrow\left[\begin{array}{c}
t=t+1, t<T \\
\text { completion algorithm, } t=T ;
\end{array}\right.
$$

5)

$$
\left(\frac{Y_{t}^{f i}}{Y_{t}^{I d i}} \neq \frac{Y_{t}^{(f i+1)}}{Y_{t}^{(I d i+1)}}\right) \wedge\left(G r_{t}^{s}=0\right) \longrightarrow\left[\begin{array}{l}
\operatorname{Reg}_{t}^{i j}=\operatorname{Reg}_{t}^{i j}-\lambda^{j}, \frac{Y_{t}^{f i}}{Y_{t}^{I d i}}=\max _{i} \frac{Y_{t}^{f i}}{Y_{t}^{I d i}} \\
\operatorname{Reg}_{t}^{i j}=\operatorname{Reg}_{t}^{i j}+\lambda^{j}, \frac{Y_{t}^{f i}}{Y_{t}^{I d i}}=\min _{i} \frac{Y_{t}^{f i}}{Y_{t}^{I d i}}
\end{array}\right.
$$

$6)$

$$
\left(Y_{t}^{f i}<Y_{t}^{I d i}\right) \wedge\left(\frac{Y_{t}^{f i}}{Y_{t}^{I d i}}=\frac{Y_{t}^{f i+1}}{Y_{t}^{I d i+1}}\right) \wedge\left(G r_{t}^{s}=0\right) \longrightarrow Y_{t}^{I d i}=Y_{t}^{I d i}-\lambda^{j}
$$

The value $\lambda^{j}$ for adjusting the values of the regulators is determined by a decision maker, and for adjusting the parameters of the indicative plan is using the fuzzy algorithm described above.

In this way, the control block ensures the transfer of the RSES from the current state to the specified one in accordance with the formed indicative plan. As a result of step $q$ of the iterative algorithm either the reallocation of the resource and the introduction of a new control action, or a return to the level of goal is setting-options 1 and 6 .

At the same time, attention should be paid to boundaries of the use of the proposed models and algorithms. This issue is multidimensional. In particular, the proposed models do not consider the microeconomic parameters, the indicators of development of municipalities that are part of the regional system. There is a limit associated with the level of detail. Similarly, as has been noted above the parameters of the macroenvironment are exogenous in the model. On the other side, the results obtained in the course of model experiments, one way or another, are based on the economic laws laid down in the model, the existing conditions, and some assumptions. In this regard, with a qualitative change in 
the state of the regional environment or the conditions for the functioning of agents, a more detailed analysis of their consequences is required. The final decision on the implementation of certain public policy measures should be based on the opinion of the decision-maker.

Development of regional ASM based on the proposed modeling concept can be used as the core of various information systems. The use of these information systems is aimed at solving the problem of providing quality information support in the implementation of development programs at the regional level. The development of the decision support system is the most perspective and fit-for-purpose [11, 12].

Scheme of implementation of information support based on ASM. In general terms, the decision support system in regional development management, in our opinion, should solve the following basic tasks:

- collection and accumulation of factual information, structured information in the form of decision rules, as well as semi-structured information in the form of ontologies and precedents;

- situation analysis using problem-oriented knowledge base with inference mechanism [13];

- formation of the forecast of situation in different macroeconomic conditions based on adaptive simulation model;

- development of a set of recommendations for the formation and correcting of the parameters of regional development management.

However, the proposed adaptive-simulation model does not allow to solve the problems of information and analytical support and requires the addition of a set of functional blocks (Figure 3).

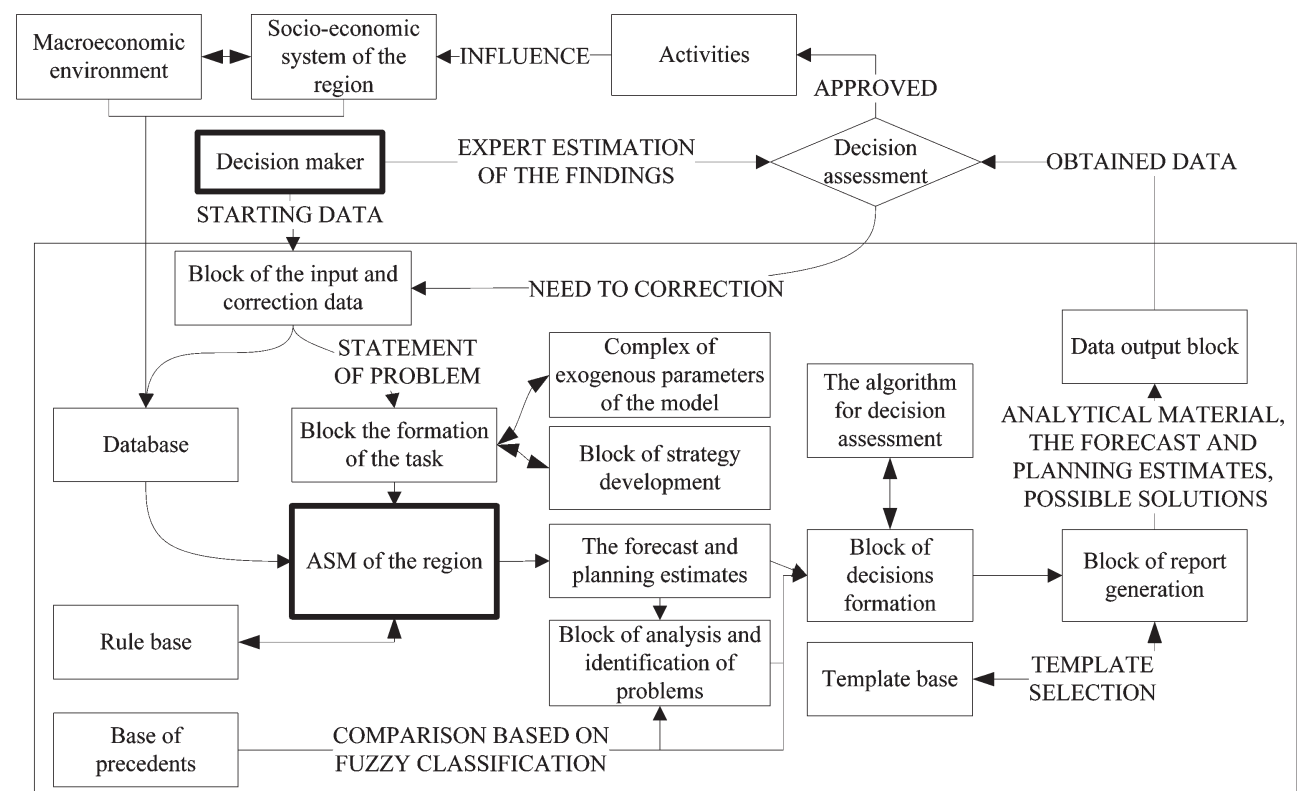

Figure 3. Scheme of the DSS organization based on adaptive simulation model

Phase 1 is the formation of a set of initial parameters. A data entry block provides filling the database with various information about the state of the control object and the 
environment. In view of the fact that database should be updated periodically, organization of monitoring is a necessary condition for DSS functioning. This makes it possible allows not only have an idea of the current and retrospective state of the control object, but also to monitor the consequences of management decisions, and accordingly to expand and improve the existing bases of rules and precedents. Processing enormous aggregation of information requires the use of modern information technology data processing and data mining. As a consequence, data storage is proposed to be organized on the basis of the OLAP concept (including through the multidimensional database properties) and Data Mining. According to experts in this field using Data Mining can look for insights in large amounts of information [14].

In addition, the input block is used to mission statement by the system user (decision maker) [15]. This phase is represented by the task formation block (see Figure 3). The need for this block is contingent on variety of practical tasks and areas of application of the DSS and the need to enter not only reporting data, but also exogenous parameters of the model, as well as the choice of development strategy. The block of strategy formation should allow to develop the general strategy of regional system development and to define a number of parameters of model even before simulation for a choice of the development direction.

Obtained the forecast and planning estimates pass to block of analysis and identification of problems. At this stage, cross-section analysis, analysis of trends and other procedures are carried out. These procedures allow to identify both the problems and the prerequisites for their occurrence. The base of precedents is used for this purpose. It contains information about the possibility of using the accumulated experience of solving problems in the process of developing solutions to new tasks. Decision support system forms a set of alternative solutions based on the forecast-planned estimates identified in the analysis of development problems. The implementation of this procedure is expected to be carried out within the solutions formation block that allows for the classification of situations and comparison with the existing base of precedents to select possible solutions based on the algorithm presented in Figure 2. The use of methods of fuzzy logic theory seems appropriate as a tool for solving such problems. This approach makes it possible to monitor the smooth variation in the properties of the control object, as well as to use its qualitative characteristics [16].

Integration of the proposed DSS based on adaptive simulation model of the region, into the activities of regional ministries and departments involves the solution of a number of issues. In particular, it is necessary to clearly define the stages of formulation of the strategic development documents, which use the capabilities of this tool. Methodological recommendations for their implementation, taking into account the use of the DSS, should be developed (or adjusted) for each of the stages. Within the framework of these recommendations, it is necessary to clearly define the list and characteristics of the used indicators, the frequency of data updates, the sources of information, the issues of coordination with other stakeholders. Based on this, a list of officials is determined, and their powers are adjusted accordingly. In addition, it is recommended to identify a focal point responsible for the implementation of the proposed system, as well as the procedure for evaluating and monitoring the effectiveness of its implementation.

Generally, the proposed DSS can become a universal tool that provides the decision maker necessary for decision-making information about the retrospective, current and future state of the regional socio-economic system. Also, this tool will allow to analyze and identify possible ways to solve the existing problems. 
Conclusion. Thus, within the framework of the study, a conceptual scheme for the implementation of the DSS in the field of regional development management is proposed. Also, the place of the adaptive simulation model in the structure of the system is determined, potential for use adaptive simulation model in the formation of forecastplanned estimates of the region's development are shown, as well as the assessment of feasibility of alternative control actions are shown. The article describes the procedure of forming the solution and the purpose of functional blocks. This tool provides the ability to work with a model complex for the end costumer, providing convenient use of tools for a person who is not an expert in economics and mathematical modeling [17].

From a theoretical perspective, the proposed tools will expand the possibilities of combination both management theory and decision support methods, intellectual information technologies, and economic and mathematical methods, modern computer simulation technologies for strategic planning of the socio-economic systems development on macro- and meso-level. The software tools have an important practical focus. The proposed design of the decision support system can be used by public authorities for determining the parameters of the medium-term development in the regions of the Russian Federation, as well as other RSES in the development of measures and mechanisms for the implementation of state economic policy.

\section{References}

1. Godina O. V., Maksimenko L. S., Savtsova A. V. Dynamic approach to strategic analysis of the innovative environment of the regional socio-economic system. Indian Journal of Science and Technology, 2016, vol. 9 (16), pp. 1-6. https://doi.org.10.17485/ijst/2016/v9i16/90048

2. Koltsaklis N. E., Dagoumas A. S., Georgiadis M. C., Papaioannou G., Dikaiakos C. A mid-term, market-based power systems planning model. Applied Energy, 2016, vol. 179, pp. 17-35. https://doi.org.10.1016/j.apenergy.2016.06.070

3. Antamoshkin N. A., Antamoshkina O. I., Hodos D. V. Modelirovanie osnovnyh ehtapov formirovaniya programmy innovacionnogo razvitiya [Basic steps of innovative development program formation modeling]. Sibirskij zhurnal nauki $i$ tekhnologij [Siberian Journal of Science and Technology], 2010, vol. 4 (30), pp. 204-206. (In Russian)

4. Nikolskij M. S. Uproshchennaya igrovaya model vzaimodejstviya dvuh gosudarstv [A simplified game model of the interaction between two countries]. Vestnik Moskovskogo universiteta. Seriya 15. Vychislitel'naya matematika i kibernetika [Vestnik of Moscow University. Series 15. Computational Mathematics and Cybernetics], 2009, vol. 2, pp. 14-20. (In Russian)

5. Buyanov B. B., Lubkov N. V., Polyak G. L. Sistema podderzhki prinyatiya upravlencheskih reshenij s primeneniem imitacionnogo modelirovaniya [Management decision support system using simulation]. Problemy upravleniya [Control Sciences], 2006, vol. 6, pp. 43-49. (In Russian)

6. Aitova J. S., Oreshnikov V. V. Podhody k modelirovaniyu vzaimovliyaniya demograficheskogo potenciala i ehkonomicheskogo razvitiya regionov Rossii [Approaches to modelling power relations of demographic potential and economic development of Russian regions]. Vestnik NGIEHI [Bulletin NGII], 2018, vol. 12 (91), pp. 69-80. (In Russian)

7. Zhang X., Hua Q., Zhang L. Development and application of a planning support system for regional spatial functional zoning based on GIS. Sustainability, 2016, vol. 8, pp. 1-17.

https://doi.org.10.3390/su8090909

8. Nizamutdinov M. M., Oreshnikov V. V. Instrumentarij prognozirovaniya izmeneniya parametrov regionalnogo razvitiya na osnove adaptivno-imitacionnogo podhoda [Tools predict changes in the parameters of regional development on the basis of the adaptive simulation approach]. The 3rd International conference "Information technologies for intelligent decision-making support ITIDS'2015". Ufa, USATU Publ., 2015, pp. 211-215. (In Russian)

9. Zakharova A. A. Integralnaya ocenka innovacionnogo razvitiya regiona na osnove nechetkih mnozhestv [Integrated assessment of innovative development of the region on the basis of fuzzy sets]. Nauchnoe obozrenie. Tekhnicheskie nauki [Scientific review. Technical Science], 2014, vol. 1, pp. 161168. (In Russian)

10. Palyukh B. V., Kakatunova T. V. Nechetkaya kognitivnaya karta kak instrument modelirovaniya innovacionnoj deyatelnosti na regionalnom urovne [A fuzzy cognitive map as a tool to model innovation 
at the regional level]. Programmnye produkty i sistemy [Software and Systems], 2012, vol. 4, pp. 128-131. (In Russian)

11. Gorelova G. V., Verba V. A., Zaharova E. N. Process prinyatiya reshenij i ego podderzhka na osnove kognitivnogo modelirovaniya [Decision-making process and its support on the basis of cognitive modeling]. Izvestiya JuFU. Ingenerniye nauki [Proceedings of SFedU. Engineering Sciences], 2005, vol. 10 (54), pp. 13-20. (In Russian)

12. Tereljansky P. V. Matematicheskie i instrumental'nye sredstva podderzhki prinyatiya reshenij $\mathrm{v}$ ehkonomike [Mathematical and instrumental supporting of decision making in the economics]. Audit $i$ finansovyj analiz [Audit and Financial Analysis], 2008, vol. 6, pp. 461-471. (In Russian)

13. Tyushnyakov V. N., Zhertovskaya E. V., Yakimenko M. V. Informacionno-analiticheskoe obespechenie situacionnogo centra kak osnova razrabotki strategij innovacionnogo razvitiya regiona [Information and analytical support of situational centers as the basis for the strategy choice of region innovative development]. Fundamentalnye issledovaniya [Fundamental Research], 2015, vol. 116, pp. 1253-1257. (In Russian)

14. Chernyahovskaya L. R., Fedorova N. I., Nizamutdinova R. I. Intellektualnaya podderzhka prinyatiya reshenij $\mathrm{v}$ operativnom upravlenii delovymi processami predpriyatiya [Intellectual decision support in the operational management of business processes]. Vestnik Ufimskogo gosudarstvennogo aviacionnogo tekhnicheskogo universiteta [Ufa State Aviation Technical University Journal], 2011, vol. 2 (42), pp. 172-176. (In Russian)

15. Pechatkin V. V. Konkurentosposobnost, konkurentoustojchivost i ehkonomicheskaya bezopasnost kak osnova sistemy monitoringa razvitiya regiona [Competitiveness, competitiveness and economic security as a basis for monitoring the development of the region]. Konkurentosposobnost $v$ globalnom mire: ehkonomika, nauka, tekhnologii [Competitiveness in the Global World: Economics, Science, Technology], 2017, vol. 12 (59), pp. 984-987. (In Russian)

16. Nizamutdinov M. M. Konceptualnye i metodicheskie aspekty zadachi modelirovaniya razvitiya territorial'nyh sistem municipalnogo urovnya [Modeling municipal level territorial systems' development: conceptual and methodical aspects]. Upravlencheskie nauki [Management Science], 2017, vol. 7 (2), pp. 2331. (In Russian)

17. Veremej E. I. Optimizacionnyj podhod k modelirovaniyu i razrabotke informacionno-upravlyayushchih system [Optimization approach to modeling and development of information management systems]. Prikladnaya informatika [Journal of Applied Informatics], 2012, vol. 6(42), pp. 34-41. (In Russian)

Received: April 02, 2019.

Accepted: June 06, 2019.

Author's information:

Albert R. Bakhtizin - Dr. Sci. in Economics, Corr. Member of RAS; albert.bakhtizin@gmail.com

Marsel M. Nizamutdinov — PhD in Engineering; marsel_n@mail.ru

Vladimir V. Oreshnikov — PhD in Economics; voresh@mail.ru

\section{Подход к решению проблемы управления стратегическим развитием региона с использованием адаптивно-имитационной модели*}

А. Р. Бахтизин ${ }^{1}$, М. М. Низамутдинов ${ }^{2}$, В. В. Орешников ${ }^{2}$

1 Центральный экономико-математический институт Российской академии наук, Российская Федерация, 117418, Москва, Нахимовский пр., 47

2 Институт социально-экономических исследований Уфимского Федерального исследовательского центра Российской академии наук, Российская Федерация, 450054, Уфа, пр. Октября, 71

Для цитирования: Bakhtizin A. R., Nizamutdinov M. M., Oreshnikov V. V. Approach to the problem of strategic management of the regional development based on adaptive simulation

* Работа выполнена при финансовой поддержке Российского фонда фундаментальных исследований (грант № 18-00-00345 (18-00-00343)). 
model // Вестник Санкт-Петербургского университета. Прикладная математика. Информатика. Процессы управления. 2019. Т. 15. Вып. 3. С. 362-374.

https://doi.org/10.21638/11702/spbu10.2019.306 (In English)

Одной из наиболее актуальных задач, стоящих в настоящее время перед органами государственной власти в Российской Федерации, является управление комплексным развитием регионов. Сложность данного объекта управления, многоаспектность существующих проблем и противоречивость целевых установок в совокупности с динамично изменяющимися условиями функционирования требуют применения современных методов и инструментов прогнозирования изменения ключевых параметров развития региона. В статье предложен подход к формированию адаптивной имитационной модели региональной социально-экономической системы. Такая модель позволяет учитывать особенности поведения экономических агентов при их взаимодействии друг с другом и внешней средой. Представлена концептуальная схема данной модели и раскрыты основные ее элементы, в том числе блоки адаптивного поведения агентов, использования ресурсов и обеспечения балансов. Отдельно выделена управляющая подсистема, включающая блоки целеполагания и регулирования. Обоснован комплекс правил, регламентирующих активизацию работы того или иного блока модели. Для реализации этой задачи проведена формализация механизма корректировки индикативного плана с применением методов нечеткой логики. Разработана база знаний нечетких правил для формирования целевых индикаторов управления развитием региональной системы. Описана схема реализации информационной поддержки управления региональным развитием на базе предложенной адаптивной имитационной модели региона. Представленный инструментарий, сочетающий методы теории управления и экономико-математические, позволит повысить эффективность разработки стратегий регионального развития.

Ключевые слова: стратегия социально-экономического развития, имитационное моделирование, адаптация, региональная система, нечеткая логика, целевые индикаторы, управление, система поддержки принятия решений.

Контактная информация:

Бахтизин Алъберт Рауфович - д-р экон. наук, чл.-корр. PAН; albert.bakhtizin@gmail.com

Низамутдинов Марсель Малихович - канд. техн. наук; marsel_n@mail.ru

Орешников Владимир Владимирович - канд. экон. наук; voresh@mail.ru

Вестник СПбГУ. Прикладная математика. Информатика... 2019. Т. 15. Вып. 3 